International Journal of Business Management and Economic Review

Vol. 4, No. 04; 2021

ISSN: 2581-4664

\title{
NEXUS BETWEEN STRATEGIC THINKING AND ENTREPRENEURSHIP DEVELOPMENT: A CONCEPTUAL FRAMEWORK
}

\author{
OBALEMO Augustine Olorunfemi \\ Department of Business Administration Nile University of Nigeria
}

http://doi.org/10.35409/IJBMER.2021.3297

\begin{abstract}
The study examined the nexus between strategic thinking and entrepreneurship. The study proxy strategic thinking as market forces and availability of resources and entrepreneurship was proxy as innovation. The study adopted conceptual research design. The study collected data from past literature review and article published in reputable international or local journals. The study developed a conceptual model to explain the relationship that existed between the two variables. The findings showed that strategic thinking will help entrepreneurs to discover new business opportunities and take advantage of such opportunities to maximize profit in the society. The study recommended that entrepreneurs should strategic think about economic factors in order to enhance innovation of business.
\end{abstract}

Keyword: Strategic Thinking, Market forces, entrepreneurship development and Innovation.

\section{INTRODUCTION}

Strategic thinking is usually associated with the competitiveness of the organisation, while entrepreneurial thinking is associated with innovation and creativity to capture opportunities. Strategic thinking is usually isolated as the "thinking" part of the strategic planning process. This wrongly implies the removal of the behavioural or "action" component of strategy thinking from the construct. Strategic thinking, just like the entrepreneurial thinking, is a mindset that encapsulates thinking, state of mind and way of behaviour. Strategic thinking places a premium on synthesis and integration and requires the ability to deal with large chunks of information, recognize patterns and visual images, and the ability to pull pieces together into a big picture so one can anticipate and adapt to changes (Pisapia, Jelenc \& Mick, 2016). A contemporary conclusion about strategic thinking is that strategic thinking skills are learnable and respond to education and training (Horwath, 2014; Sloan, 2013).

Strategic thinking has been increasingly interested in strategic management area over recent decade and many studies have referred to the significance of strategic thinking in managers. Strategic thinking is accounted as one of the two main characteristics of outstanding performance leaders. They see organizations as they should be, not as they are. Hence, strategic thinking is a prelude to design an organization future. Strategic thinking characterized with recognition, leadership, creativity, eye-bird view, long-term horizon, and opportunism, as well as many other mental and personality abilities may ensure an organization success and effectiveness (Goldman, 2005). 


\section{International Journal of Business Management and Economic Review}

Vol. 4, No. 04; 2021

ISSN: 2581-4664

The major problem of entrepreneurs is utilization of resources in order to produce goods and services to add value to the existing product or new product that will stand out for longer period of time. Entrepreneurs have strategic thinking problem such as market forces problem and availability of resources such as money, men, material and machine that are use in the production of goods and services. The study realized that there is a gap in literature since no empirical studies link the two variables to together. The study used strategic thinking which is measures as market forces and availability of resources. The study also used entrepreneurship which is measure as innovation.

The objective of this study is to examine the nexus between strategic thinking and entrepreneurship development.

. The specific objectives are:

1. Determine the link between market forces and innovation

2. Evaluate the link between availability of resources and innovation

In line with these specific objectives, conceptual hypotheses were formulated as follows:

$\mathrm{H}_{01}$ : There is no relationship between market forces and innovation

$\mathrm{H}_{02}$ : There is no relationship between availability of resources and innovation

\section{Concept of Strategic Thinking}

Strategic thinking is a way of solving problems that combines the rational and convergent approaches with creative and divergent thought processes and is intertwined with ongoing action processes (Bonn, 2005; Ratcliffe, 2006). According to Abraham (2005) strategic thinking is the process of finding alternative viable strategies or business models of competing or delivering customer value that is done as part of the strategic planning process. Its challenge is to find a different way to do what the organisation now does or to adopt a business model different from its competitors. This is "finding your own race to run and win it". It is about "walking in your customer's shoes", spotting where value lies then organising to deliver it. This translates to a common definition of strategic thinking: ability for opportunity identification, satisfaction of needs and creation of value. Strategic thinking refers to special way of thinking, which is known as strategy architecture skill. Strategic thinking is simply an intentional and rational thought process that focuses on the analysis of critical factors and variables that will influence the longterm success of a business, a team, or an individual. Strategic thinking includes careful and deliberate anticipation of threats and vulnerabilities to guard against and opportunities to pursue. The measures of strategic thinking are market forces, economic realities and available resources (Ratcliffe, 2006).

\section{Market forces}

The actions of buyers and sellers that cause the prices of goods and services to change without being controlled by the government: the economic forces of supply and demand (Merriam, 2020). The way that the behaviour of buyers and sellers affects the levels of prices and wages, without any influence from the government (Longman, 2020). A market force is a factor that has some ability to affect change in a market. Market forces determine the price and quantity of a good or service in a market(Black \& Myles, 2009). Market forces occur naturally in a free market economy and are controlled by government intervention(Black \& Myles, 2009).. 
International Journal of Business Management and Economic Review

Vol. 4, No. 04; 2021

ISSN: 2581-4664

\section{Available resources}

Longman (2003) asserts that availability refers to resources ready to be used, able to be used or that can easily be found and used. Onyejiemezie (2002) noted that availability is a state of making provision for a satisfactory standard requirement. The resources of an organization or person are the materials, money, and other things that they have and can use in order to function properly (Collins English Dictionary, 2020). Available resources are something that a firm possesses or employs (Collins English Dictionary, 2020).

\section{Concept of entrepreneurship}

Entrepreneurship has not lent itself to a single meaning or explanation. The term entrepreneurship has been conceptualized in various ways by different authors in different ways. However, the basic aspect on concept of entrepreneurship remains constant. For instance, entrepreneurship is the eagerness or capability of entrepreneurs to find out investment opportunities in a dynamic business environment which create and run a firm profitably based on the well-known opportunities (Gana, 2008). It is a person who established a new business or a new way or approach to an old business or idea or a perfect way of giving the market place a product or service by using scare resources in a new method under conditions or risk (Ihekwoba, 2007). Entrepreneurship is clear manifestation of effective exploitation of human resources as indicated in creative performance (Iheonunekwu, 2003). Entrepreneurship is a dynamic state of creating product and services that cause incremental wealth (Hisrich \&Peters, 2007).

\section{Innovation}

Innovation is an application of technological, institutional, human resources and discoveries to productive processes, resulting in new practices, products, markets, institutions and organisations that need organizational improvement or performance in terms of sales, profitability and market shares(Zwingina \& Opusunju, 2017). Innovation in SMEs business can be a product, process, and marketing used in order to increase performance of business in terms of sales volume (Zwingina \& Opusunju, 2017).

Innovation is a process of creating new ideas or adding value to existing ideas in organizational products or services (Zwingina\& Opusunju, 2017). It is a process of creating things from nothing (Opusunju, Abubakar \& Mustapha, 2020). According to Seng, Yusof and Abidin (2011), there are eight types of innovation that organization practice, to them; they are product, process, incremental; radical, administrative, technology; market and value innovations. Product Innovation is the development of new products, changes in the design of established products, or the use of new materials or components in the manufacture of established products (Policy Study Institute, 2010). Process innovation is the changes in the manner firms produce the end product for the wellbeing of its consumers in the market (Seng Yusof \& Abidin, 2011). Process innovation is said to be the implementation of a new product or significantly improved product using production process or delivery method to achieve it and it unique changes in techniques, methods, skills, equipment and software (Guillaume, 2010). However, administrative innovation is a new system of administration that aid in the achievement of astated goal or objectives in the organization (Oslo Manual, 2005). Incremental innovation is the ability of a firm to repeatedly changes the product attributes' or design the product in a new way that satisfies customers in the market. Radical innovation is a total change in the output of the product which is new to the business organisation, industry or market resulting in a transformation of the economics of a 


\section{International Journal of Business Management and Economic Review}

Vol. 4, No. 04; 2021

ISSN: 2581-4664

business (Seng et al., 2011). Technology innovation is the process of using modern equipment such as computer, machines or efficient tools to improve product quality or attribute to efficiently and effectively sales to the consumers (Seng et al., 2011)

No business survives and flourishes in today's competitive business environment without rightful thinking on the part of its owners, managers and employees toward its growth and development of Nigeria economy. It is argued by psychologists, management scholars, researchers and scientists that human beings as higher animals require higher thinking skills to survive, respond to threats and opportunities, and manage a business towards competiveness in an economy (Morris, 2003; Pisapia, Sun-Keung Pang, Fatt Hee, Lin and Morris 2008;Pisapia, 2011; Oghojafor, 2012).It is not just about thinking endlessly without Nigeria proffering solution to a problem, but with the ability to come up with concrete, reliable and achievable plans of action for the growth of Nigeria economy (Morris, 2003; Pisapia, Reyes-Guerra, \& Yasin2006; Gladwell, 2006; Pisapia, 2011). This necessary to survive the weak labour market situation in Nigeria that has caused a lot of constraints to entrepreneurial businesses and strategic thinkers Hence, the reason why HR experts and other business professionals regard thinking as a skill which a prospective job applicant and employee must possess in order to be considered for strategic organisational position (Pisapia, et al. 2008; Armstrong, 2011; Watson \& Reissner, 2014). Today's competitive business world demands a high level of critical thinking, variously called strategic thinking skills, systems thinking, solutionthinking, future and forward thinking, longer-term thinking, and high level thinking (Haines,2006; Synder and Synder, 2008; Pisapia, 2011). This is a skill required to meet unforeseeable future challenges, for planning business operation, growth and survival (Silinevica, 2011). Acquiring theseskillsis a major challenge facing the student, the youth, the entrepreneurial and business manager in today"s depressed economy (Pisapia, et al. 2008; Kargin and Aktas,2012). Thus, most developing countries face similar constraints and challenges in strategic thinking skills applicationwhen it comes to the establishment of business, development of the business and maintaining effective employment relationship (Centre for Critical Thinking, 1996c)

Many analysts assert that entrepreneurship is beneficial for economic growth and even more so during the economic crisis, especially when given the right opportunities(UNCTAD 2004). Berglund (2005) noted that entrepreneurs disrupt prevailing equilibriain the economic market through innovation, thereby changing various economic benchmarks enabling development within the economy. Van Praag \& Versloot (2007) believe entrepreneurship contributes to the economic development through four main categories "employment generation, innovation, productivity and growth, increasing individual's utility levels". From the perspective of different scholars, the author can conclude that Entrepreneurship fosters economic growth during the economic crisis by providing jobs, reducing unemployment, creating products, encouraging and increasing savings. The gains of entrepreneurship can only be realised, however, if given the right opportunities government needs to create a right environment and policymakers need to make policies that will aid and encourage the growth of businesses(Osalor 2016b.)

\section{Entrepreneurship and Strategic thinking: Conceptual Model}


International Journal of Business Management and Economic Review

Vol. 4, No. 04; 2021

ISSN: 2581-4664

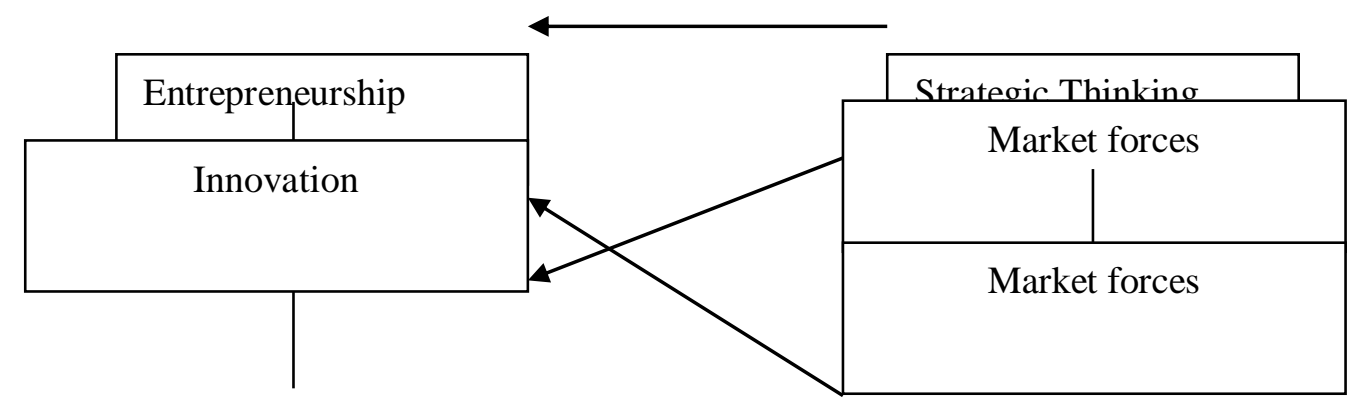

\section{Researcher Model:}

This model is conceptualized since there is no empirical studies that link entrepreneurship and strategic thinking. This model explained that entrepreneurship is function of strategic thinking in any organization. The ability for an entrepreneur to think strategically in business will enhance his or her entrepreneurship skills such as innovation. The model believes that there is link between entrepreneurship and strategic thinking in organization that strategic thinking will help entrepreneurs to discover new business opportunities and take advantage of such opportunities to maximize profit in the society. The model believe that managers who think strategically understand the market forces of demand and supply in order to ascertain when to produce a particular product or when to adopt a particular marketing skills or reduce prices of goods in order to gain competitive advantage in the market. It also expresses that entrepreneurs as innovative of news skills and product will need strategies to again competitive advantage in the market, This strategic thinking in the available resources such as money, men, material etc. The entrepreneurs need money to improve on innovation of product or introduce new product in the market. The research and development which will enhance new product development needed money in order to actual the process and bring out good and quality product that will marketable and high in demand in the society.

It is pertinent to note that entrepreneurs bring innovative product but must be limited to the availability of resources such as material and men as well as machine. The raw material availability is the determinant of entrepreneurs innovation. The activities of innovation can be successful if the entrepreneurs think strategically by observing the market forces between demand and supply as well as the availability of resources in the location of his/her established business.

Also, to support the above point, Mahmood and Seyed (2013) conducted a study on the relation between strategic thinking dimensions and the value of entrepreneurship of managing directors in Mashhad cooperative companies. In this survey, strategic thinking and its' dimensions contain systematic view, concentrate on object, intelligently opportunity saving,concentrate on time and pioneer with phenomenon are as dependent variables and entrepreneurship ofmanaging directors in Mashhad cooperative companies is as independent variable. Also, gender, age,educational level, marital status and experience are considered as moderator variables. This research is from 


\section{International Journal of Business Management and Economic Review}

Vol. 4, No. 04; 2021

ISSN: 2581-4664

descriptive and solidarity method type and is done by utilizing the survey and field method and by using standard questionnaires. Statistical population is contained all the managing directors of Mashhad cooperative companies. The volume of sample is 256 ones. The result shows that the value of entrepreneurship is in highlevel and there are significant relation between strategic thinking and its' dimensions with the rate ofmanagers' entrepreneurship.

\section{Economic Theory of Entrepreneurship}

The argument that supported the economic theory of entrepreneurship is that some economic factors are the main drive behind any entrepreneurial activity. They observe that the organization or the environment cannot change itself except in reaction to something and that something is the economic factors like land, labour, capital or other resources that create economic value in a product and services. This gives credence to the fact that the entrepreneur is an agent of economic change. The creativity, ingenuity of the entrepreneur to take the calculated risk to produce a new product or services that will solved the problem of the consumers as well as make some profit for the entrepreneur is the change that occurs in the environment.

Kirsner (1999) observes that competition can ignite a motivational spirit for entrepreneurs to acquire more skills that will equip them to compete better with other entrepreneurs. Women are not exceptions since ladies entrepreneurs play an important role that is peculiar to them in the market when they exercise high sense of management, control and coordination to the process of producing products or services. This distinct roles draws them to entrepreneurship where they virtually succeed as agents for economic change.

This theory is apply to this study since it looked at factors as the main drive behind any entrepreneurial activity and these factors are economic factors such as availability of resources and market forces. These factors are that makes an entrepreneur to be worry about how to overcome them and ensure that he/she brings about good innovation.

\section{METHODOLOGY}

The study adopted conceptual research design. The reason for using conceptual research design is that the researcher used concept to explain the link between the two variables since no empirical studies link the two variables together. The study used orange fruit juice production in Benue State to explain the variables. The study collected data from past literature review and article published in reputable international or local journals. The study developed a conceptual model to explain the relationship that existed between the two variables.

\section{FINDINGS}

From the model presented in figure 1, the researcher believes that there is a relationship that existed between entrepreneurship and strategic thinking in an organization. The study found that strategic thinking enhanced entrepreneurship by using orange fruit juice production in Benue State of Nigeria. The study realized that strategic thinking are measured by market forces and availability of resources and these factors determine entrepreneurship in terms of innovation, that is bring new product or re-branding the existing product in the market. 


\section{CONCLUSION AND RECOMMENDATIONS}

The study concluded that entrepreneurship is function of strategic thinking in any organization. The ability for an entrepreneur to think strategically in business will enhance his or her entrepreneurship skills such as innovation. There is a link between entrepreneurship and strategic thinking in organization that strategic thinking will help entrepreneurs to discover new business opportunities and take advantage of such opportunities to maximize profit in the society. Managers who think strategically understand the market forces of demand and supply in order to ascertain when to produce a particular product or when to adopt a particular marketing skills or reduce prices of goods in order to gain competitive advantage in the market.

The study therefore recommended that:

1. Entrepreneurs should strategic think about economic factors in order to enhance innovation of business

2. Entrepreneurs should try to discover more opportunities within their environment ensure that they utilized the available resources in order to bring about innovative product

\section{REFERENCES}

Black, N. H. \& Myles, G.(2009). "Market Economy." [Online], Available: http://www.oxfordreference.com/view/10.1093/acref/9780199237043.001.0001/acref9780199237043-e-1924? rskey=eaSXjc\&result=1,

Zwingina, C. T. \& Opusunju, M. I.(2017). Impact of Innovation on the Performance of Small and Medium Scale Enterprise in Gwagwalada, Abuja. International Journal of Entrepreneurial Development, Education and Science Research, 4(1) 31-45

Opusunju, M. I., Abubakar, M. B. \& Mustapha, N. M.(2020). Innovation and competitive advantage in Ero water company in Abuja, Nigeria. Ilorin Journal of Human Resource Management, 4(2)

Seng, L.K., Yusof, N. A. \& Abidin, N. Z. (2011). Types of Innovation Implemented by Housing Developer in Developing Countries. International Journal of Academic Research. 3(3), $614-618$

Oslo M. (2005).Guidelines for collecting and interpreting innovation data. (3rded). Organisation for Economic Co-operation and Development \& Eurostat

Pisapia, J., Jelenc, L., Mick,A. (2016): The Foundations of Strategic Thinking: Effectual, Strategic, and Causal Reasoning,inRaguž, I., Podrug, N., \& Jelenc, L. (Eds.) Neostrategic Management. pp. 45-55. Heidelberg, de: Springer International Publishing.

Mahmood, G. \& Seyed, M. R. F. (2013). Study of Relationship Between Strategic Thinking Dimensions and Entrepreneurship. Middle-East Journal of Scientific Research 13 (2): 137-144, 